\title{
Phonological Variations among Mandaya Dialects: A Multiple Case Study
}

\author{
Arnold M. Duping \\ Institute of Teacher Education, Davao del Norte State College, Philippines
}

\begin{abstract}
This multiple case study analyzes the phonological variation of Mandaya dialects among four municipalities in Davao Oriental. Purposeful sampling, in-depth interviews, sorting and classifying of words according to phonological structures in data analysis were employed. Findings revealed that the Mandaya dialects consisted of 23 segmental phonemes, 17 consonants: /b/, /k/, /d/, /g/, /h/, /l/, /l $1 /, / \mathbf{m} /, / \mathbf{n} /, / \mathbf{l} /, / \mathbf{p} /, / \mathbf{r} /, / \mathbf{s} /$, $/ \mathrm{t} /, / \mathbf{w} /, / \mathrm{y} /$ and $/ \mathbf{2} / ; \mathbf{6}$ vowels: $/ \mathrm{a} /, / \mathrm{e} /, / \mathrm{i} /, / \mathrm{o} /, / \mathrm{u} /$ including the schwa sound $/ \partial /$. All these phonemes can be found in Tarragona, Manay and Caraga except for phoneme $/ \mathrm{h} /$. Similarly, Cateel has also 22 sounds with schwa sound not found. Consonant clusters were also evident in the medial position or in the beginning of the syllables such as the cluster / $\mathrm{mp} /$ for the word /ompos/ which means grandchild. Initial consonant clusters were also found mostly from the loan words such as the cluster /gr/ in /grin/ which means green. Generally, the phonological variations of the dialects among the four municipalities center to three distinct phonemes: $/ \mathrm{h} /, / \mathbf{l} \mathbf{l} /$ and $/ \partial /$. These variations were attributed to the influence brought by migration, intermarriages, social media, and the influx of tourist exploring the nature of Davao Oriental.
\end{abstract}

Key words: Phonology, Mandaya, Language Variations, Dialects, Multiple Case Study

\section{INTRODUCTION}

$\mathrm{T}$ he Mandaya children who speak their mother tongue at home and learning English at school encounter problems in their beginning years in education. It is because they begin learning English, that is far from their language spoken at home. This leads to poor comprehension on instructional materials because of too culturally distant and strange contents. The worst is young learners may tend to drop from school.

To counter this problem, teachers have resorted to traditional way of teaching language such as rote teaching methods or grammar-translation method because also of their inadequacy in understanding the prescribed languages of instruction. As a matter of fact, the Department of Education has resulted to implement the MTBLE through the DepEd Order No 28, S. 2013- the additional guidelines to DepEd Order No. 16, S. 2012. The Mandaya young learners in Davao Oriental are taught in their native tongue during their first three years in school. However, the standard dialect Cebuano is used instead, which is also a foreign to them.

Theoretically, the need to value the different dialects of a language while preparing textbooks and other instructional materials by the experts must be considered. But as mentioned above, only the standard variety has been used and taught in schools (Cheshire, 2005). The non-standard dialects (like Mandaya) have been officially unacceptable in schools (Rosenberg, 1989). However, the Mandayas go to schools from both standard and non-standard varieties (Cheshire, 2007). Thus, there has been a mismatch between the varieties used at schools and those used at home.

Still in the Philippines setting, a well-meaning pupil necessitates to communicate in the language that the schoolteachers have prescribed aside from his/her own (Belarmino, 2000). Because of this and because the medium of instruction is unfamiliar to them, Baguingan (cited in the study of Saranza, 2014) has stated that school children already considered school as a traumatic place. She has further revealed that kids find it difficult to speak not only their mother tongue, but also to master the Filipino and English and other language as well which is Cebuanao as lingua franca used in the instruction. Cebuano as recognized language for instruction in the MTBLE program in Davao Oriental is still the language that the Mandaya learners hardly to understand. Mandaya learners have used Mandaya at home, but learn Cebuano, Filipino and English at school.

This dilemma in the educational scenario is also true to some other countries which have pointed out that the used of dialect negatively affect education. For instance, in Netherlands, Hagen (1989) has reported that dialect speakers experience problems in their education with respect to learning and achievements of language skills and other school subjects. It is generally said that dialect speakers face various challenges in their learning (Chambers, 2008). For example, dialect speakers face challenges in learning to read in the classroom (Hudson, 2001). This is because the students are less likely to find predictable features of their dialect in textbooks. Reaser and Adger (2007) stated that African American dialect speakers have more difficulty to read because of dialect differences. In such cases, standard speakers are more likely to have an advantage over dialect speakers (Romaine, 2000). Many materials used in classrooms are prepared in a standard dialect and students speaking the standard are familiar with the sounds and vocabulary of the standard dialect. So, it is easier for the standard dialect speakers to read and understand than for the students speaking the non-standard dialect (Wundimo, 2015).

This problem is experienced more in a multi-lingual country like the Philippines wherein multi-linguals exist not only in Luzon and Visayas but as well as in Mindanao. In this 
island, different ethnographic groups thrived with different unique cultures that usually engage conversation or communication with other individuals in another ethnic group. With this communication needs, people learn to use their mother tongue but as well as the language or dialects of their neighbouring tribes or groups. However, it is only their mother tongue that reflects most of their identity. In relation to the sociolinguistic theory, the language variation may exist according to the context of ethnicity, social class, sex, geographical location, age, and another factor. Linguists have pointed out that variations can happen in phonology, morphology, syntax, and semantics. Further, it is also assumed that language varies in sounds or pronunciation of words or vocabulary, grammatical structure (Santos and Hufana, 2008 as cited by Pasion, 2010). These elements of language can be linked to the external factors like geographical or social group. The variation is geographical if the language varies according to utterance, intonation, vocabulary and morphology and grammar in relation to its geographical location of the speakers. The difference of the language caused by its elements is called regional variation or dialect. On the other hand, social variation refers to the different use of the language by different people in terms of their status, position, or group. Because of these variations, we have what we called variety of language.

According to Fermin as cited by Peregrino (2002), the continuous development of the variation of language is attributed to the socialization of an individual to other members of a certain group or even with the out-group in the society. This continuous socialization exposed him to different aspects and characteristics of the language used. The diverse culture, status and lifestyle are factors that cause language to vary. This happens to a place with different language, culture and status of people living like Mindanao.

The differences that have been cited above are evident in Davao Oriental as home of the large number of the Indigenous People (IP) called the Mandaya. The Mandaya tribe is included in the list of 110 ethnic tribes in the Philippines. The term Mandaya is derived from the root word daya, which literally means "upstream" or "upland." Aside from Davao Oriental, Mandaya also thrives in some parts of Surigao Del Sur, in Davao del Norte, and in Compostela Valley and some parts of Agusan del Sur (NCIP, 2012). Of these places, Davao Oriental has the largest population of Mandaya people. It consists of one (1) city and ten (10) municipalities and politically divided to two (2) districts. The municipalities of Boston, Baganga, Caraga, Cateel, Manay and Tarragona belong to District 1. District 1 is known to be the home of Mandaya speakers because they occupy the largest portion of the total population of the district.

The Mandaya is an Austronesian language of Mindanao in the Philippines. This is intelligible with the Mansaka and spoken in the municipalities of Davao Oriental Province. The dialect is often spoken in ordinary and informal conversation whether at home or in any speech situation. It did not become the medium of instruction because Mandaya people prefer to use Bisaya, Tagalog or English in formal events or functional conversation especially with the outgroup. Belarmino (2000) has supported the claim by stating that language could only be used in relating to with the members themselves in the in group but now with the outgroup because of fear of communication breakdown.

Although Mandaya is one ethnic group, they are still divided and separated by mountains, rivers, and seas. Because of these geographical divisions, it is believed and observed that Mandaya dialects being used by the native speakers have distinct variations from one municipality to another. This is very evident in the peculiarities on structure and sounds of Mandaya speakers from one place to another. Mandaya dialects spoken by the municipalities of Davao Oriental particularly on the coastal towns are varied.

The variations of the Mandaya dialects in Davao Oriental are dependent on the places where it is used. Dialect variations can be in the form of word formation, sounds and other speech aspects. Knowing these variations is the goal of this study. Moreover, the result of this study may help preserve the Mandaya dialects and can be used for producing localized instructional materials particularly in teaching reading in the mother tongue, which is Mandaya.

The purpose of this qualitative multiple case study is to determine the phonological variations among Mandaya dialects in the municipalities of Tarragona, Manay, Caraga, and Cateel of Davao Oriental. This anchored to the language variation theory that refers to the small variations which occur in language, and which are determined by external, social factors. These variations can and do lead in time to language change. They contrast with variations in language which are motivated by internal factors - structural features of a language - which can also lead to change, especially when this internal variation occurs during first language acquisition (Chambers, 2003).

Through this study, the gradual extinction of Mandaya dialects which is now felt by Mandaya speakers of Davao Oriental can be prevented. The result of this study could serve as basis in the production of Mother Tongue Basic Language Education reading and instructional materials in Mandaya. More importantly, this study on the variations among Mandaya dialects can be a strong force in understanding the differences of individuals, groups, communities, province, and the nation. This will further identify the Mandaya from the rest of the indigenous group of the country.

\section{Research Questions}

1. What are the phonological variations of Mandaya dialects?

2. How do variations occur in Mandaya dialects? 


\section{METHODOLOGY}

This study utilized the multiple cases study research design. Creswell (1998) stated that case study research involved the study of an issue explored through one or more cases within a bounded system (i.e., a setting, a context

To get different perspectives on the problem, process and issues of the event, the participants were purposively selected according to the inclusion criteria that they must be native of the place and certainly speaking Mandaya language at home and at the community. Free and Prior Informed Consent (FPIC) or the Informed Consent Form was secured from the informants/participants before the interview commenced. This was in recognition to the IPs intellectual contribution in the development of knowledge, and their rights over these knowledge and resources.

After the approval, the researcher had a community visit and rendered a courtesy call to the local officials of the community together with the contacts in the community. This study employed a face-to face interview with the participants in documenting their dialects using a prepared interview guide. The interview was done in their home or in any place that they were best comfortable with.

The interview information was compiled to ensure data collection efficiency, quality, and consistency across interview and to make sure all the information set out to be collected were captured. This was done better by using Audiorecorder to record the interview and the digital camera to capture pictures of the actual conduct of the study upon the approval of the informants. Note taking was also utilized as it was wise to manually write the key informant's comments while conducting the interview. However, this required the researcher's balancing act as to writing and listening.

This study used the Miles and Huberman's framework for qualitative data analysis (Miles and Huberman, 1994). This framework had three components which comprised of data reduction, data display and drawing and verifying conclusions that eventually interact through the analysis, according to Punch (2005). These components involved coding, memoing and developing propositions.

After transcription, linguistic features of the language were carefully sorted for the thorough linguistic analysis to determine the phonological variations among Mandaya dialects from each location. After analysing the variations of Mandaya dialects within the municipality, these were analyzed and compared to other locations to see the similarities and differences of variations that had occurred.

Moreover, after the interpretation of the gathered data, validation was done by the researcher being a Mandaya himself.

\section{FINDINGS}

The phonological variation among Mandaya dialects is concerned with sounds and the way they pronounce words.
It also refers to the differences of phonemes or sounds of a certain language. For every language of the world has a set of meaningful sounds. A distinct sound becomes meaningful if it can change the meaning of the words by deletion or omission. In this study, the differences of the phonemic sounds in the language may mean that the changes of the meaning but as well as basis of identifying the certain group sharing the same way of speaking the language.

The following phonological aspects gave interest to the researcher to focus on. First is the phoneme $/ \mathrm{h} /$; second is the phoneme $/ \Xi /$ and the third one is the glide $/ 1 /$ or $/ 1 \sim 1 /$ and fourth is vowel lengthening of phoneme /a:/ and /u:/. Table 1 below clearly shows the variation of consonant and vowel phonemes among the four cases of Mandaya dialects which are mostly occurred in the medial position. It is also noted that phonemes that vary have the same place of articulation as that of the base morpheme. As shown in the table, the word 'mapula' /mapulah/ (red) is evident in Cateel. The change of lateral /l/ to glide $/ 1 \sim 1 /$ is evident in Caraga; the change of $/ 1 /$ to $/ \mathrm{y} /$ is heard in Manay while the change of $/ \mathrm{l} /$ to $/ \mathrm{w} /$ is evident in Tarragona. However, there might be occurrence of these phonemic changes in other places.

The word 'ngani' /nanih/ (here) is evident in Manay and Caraga while the change of the phoneme /i/ to /a/ is evident in Cateel and Tarragona.

Table 1: Phonemic Variation of Mandaya Dialects among the Four Municipalities

\begin{tabular}{|c|c|c|c|c|}
\hline \multirow{2}{*}{ Morpheme } & \multicolumn{4}{|c|}{ VARIATION } \\
\cline { 2 - 5 } (red) & Cat & Car & Man & Tar \\
\hline $\begin{array}{c}\text { mayayag } \\
\text { (yellow) }\end{array}$ & mayayag & al'lal'lag & mal'lal'lag & Antiyado \\
\hline $\begin{array}{c}\text { wala } \\
\text { (none) }\end{array}$ & wala & al'la & mapuya & Wa \\
\hline $\begin{array}{c}\text { karahay } \\
\text { (frying pan) }\end{array}$ & karahay & al'la & kal'la & Kawa \\
\hline $\begin{array}{c}\text { gakuwang } \\
\text { (lie down) }\end{array}$ & gakuwang & gakul'lang & gakul'lang & Gakuyang \\
\hline $\begin{array}{c}\text { mapanaw } \\
\text { (walk) }\end{array}$ & mapanaw & mapanaw & mopanaw & Mapanaw \\
\hline $\begin{array}{c}\text { ngani } \\
\text { (here) }\end{array}$ & ngini & ngani & ngani & Ngini \\
\hline
\end{tabular}

The Phoneme /h/

The next table shows that phoneme $/ \mathrm{h} /$ is evident to both Cateel and Tarragona such as in the word 'hawid' /hawid/ (hold). The deletion of the phoneme $/ \mathrm{h} /$ is evident in Caraga and Manay such as /awid/. It is learned that the phoneme $/ \mathrm{h} /$ is prominent among Cateel Mandaya however, it 
is absent among speakers in Manay and Caraga but with only few using the phoneme in Tarragona. The use of phoneme $/ \mathrm{h} /$ by the speakers are sometimes interchanged with the vowels sound like /a/ and /i/ which can be seen in the following words such as "kaoy"/ka oy/ for tree; "angin" for air and "awid" for the verb to hold and vice versa for Manay, Caraga and Tarragona speakers. However, there are limited few speakers in the lowland that is heard using the $/ \mathrm{h} /$ phoneme. These speakers are already influenced by migration, education, and technology and the pressure to be liked by others in the urban areas. The phoneme $/ \mathrm{h} / \mathrm{can}$ be an additional phoneme of Caraga and Manay due to due to recent innovations in the language. This may be limited only to speakers who are exposed to English or other foreign languages and may be acquired only by the younger speakers of each language (Bollas, 2013).

This is attributed to the influence of many languages coming from different group of people like Bisaya from Visayas, and Ilokano from Luzon who went to Cateel for resettlement. Intermarriages have also been pointed out as another factor why the phoneme $/ \mathrm{h} /$ is dominant in Cateel. Another alarming factor presented why languages change in Cateel is the desire of the people to blend with these migrants, travellers, and tourists coming in and out from their municipality not mentioning the discrimination issues.

Table 2: Variation of Phoneme /h/ in Mandaya Dialects

\begin{tabular}{|c|c|c|c|c|}
\hline \multirow{2}{*}{$\begin{array}{c}\text { Morphem } \\
\text { e }\end{array}$} & \multicolumn{4}{|c|}{ Variation } \\
\hline & Cateel & Caraga & Manay & Tarragona \\
\hline $\begin{array}{l}\text { Bayo } \\
\text { (face) }\end{array}$ & $\begin{array}{l}\text { bayho } \\
\text { /bayho:/ }\end{array}$ & $\begin{array}{l}\text { bayo } \\
\text { /bayo:/ }\end{array}$ & $\begin{array}{l}\text { bayo } \\
\text { /bayo:/ }\end{array}$ & $\begin{array}{c}\text { kaimu } \\
\text { /ka.imu:/ }\end{array}$ \\
\hline $\begin{array}{l}\text { tuhod } \\
\text { (knee) }\end{array}$ & $\begin{array}{c}\text { tuhod } \\
\text { /tu:hod/ }\end{array}$ & $\begin{array}{c}\text { tud } \\
/ \mathrm{tu} \sim \mathrm{d} /\end{array}$ & $\begin{array}{c}\text { tud } \\
/ \mathrm{tu} \sim \mathrm{d} /\end{array}$ & $\begin{array}{c}\text { tud } \\
/ \mathrm{tu} \sim \mathrm{d} /\end{array}$ \\
\hline $\begin{array}{l}\text { hagdan } \\
\text { (stairs) }\end{array}$ & $\begin{array}{l}\text { hagdan } \\
\text { /hagdan/ }\end{array}$ & $\begin{array}{l}\text { agdan } \\
\text { /agdan/ }\end{array}$ & $\begin{array}{c}\text { agdan } \\
\text { /agdan/ }\end{array}$ & $\begin{array}{l}\text { agdan } \\
\text { /agdan/ }\end{array}$ \\
\hline $\begin{array}{l}\text { ginhawa } \\
\text { (breath) }\end{array}$ & $\begin{array}{c}\text { Ginhawa } \\
\text { /ginha.wah/ }\end{array}$ & $\begin{array}{c}\text { iginawa } \\
\text { / } \text { Pigina.wah/ }\end{array}$ & $\begin{array}{c}\text { iginawa } \\
\text { / } \text { Pigina.wah/ }\end{array}$ & $\begin{array}{c}\text { ginawa } \\
\text { /gina.wah/ }\end{array}$ \\
\hline $\begin{array}{c}\text { kahoy } \\
\text { (tree) }\end{array}$ & $\begin{array}{c}\text { kahoy } \\
\text { /ka:hoy/ }\end{array}$ & $\begin{array}{c}\text { kaoy } \\
\text { /ka:oy/ }\end{array}$ & $\begin{array}{c}\text { kaoy } \\
\text { /ka:oy/ }\end{array}$ & $\begin{array}{c}\text { kaoy } \\
\text { /ka:oy/ }\end{array}$ \\
\hline $\begin{array}{c}\text { humay } \\
\text { (rice) }\end{array}$ & $\begin{array}{l}\text { omay } \\
\text { /omay/ }\end{array}$ & $\begin{array}{l}\text { umay } \\
\text { /Pumay/ }\end{array}$ & $\begin{array}{c}\text { umay } \\
\text { /Pumay/ }\end{array}$ & $\begin{array}{l}\text { humay } \\
\text { /humay/ }\end{array}$ \\
\hline
\end{tabular}

In the case of Tarragona, aside from the reasons mentioned aboved, its proximity to Mati City, the capital of the province is pointed out as the factor. Only Caraga and Manay have claimed that the phoneme $/ \mathrm{h} /$ does not exist on Mandaya phonology. However, changes have brought by technology and education, phoneme $/ \mathrm{h} / \mathrm{can}$ now be heard to only few particularly those with high economic status, educational level and living in the low land places.

The Glide /1/

Table 3 presents the variations on the use of phoneme /1 1/ across the four cases of Mandaya dialects. The glide /1/ is very evident among Mandaya speakers in Caraga, Manay and Tarragona, only few uses it in Cateel. As gleaned in Table 41, the use of the dental glide /l 1/ like in the word, 'mapul'la' /mapul la/ meaning red; gakul'lang /gakul lan/ meaning lie down is very much evident in Caraga and Manay. The change of phoneme /l 1/ to /1/ as shown in the word 'bulawan' /bula.wan/ (gold) is evident in Tarragona while the change of glide $/ \mathrm{l} /$ to $/ \mathrm{w} /$ is also evident in Cateel as shown in the word 'buwawan' /buwa.wan/ (gold). The phoneme /1 1/ can be seen both in the medial position such as in /gakul lang/ (to lie down) and in the final position as in /i:kol 1/ (laugh). There are no cases that can be found that the phoneme $/ 1 \sim 1 /$ is found in the initial position.

The phoneme glide /1/ or /1 1/ is used by Mandaya speakers in their conversation. Aside from the reasons mentioned earlier, variations are observed in this aspect because the glide /// is slowly fading among speakers. As a matter of fact, the researcher has observed during the gathering of data that there are some others particularly those in the lowland do not resort to gliding anymore but use the alveolar lateral /1/ such as "pula" or red instead of 'mapul'la'. As presented on the table, other speakers have resorted to substitution of phoneme glide $/ \mathrm{l} /$ to phoneme $/ \mathrm{y} /$ or $/ \mathrm{w} /$ as shown in the following words: mapul'la to mapuya in Cateel; bul'lak to buwak in Manay.

Table 3: Variation of Phoneme Glide /1 1/ in Mandaya Dialects

\begin{tabular}{|c|c|c|c|c|}
\hline \multirow{2}{*}{$\begin{array}{l}\text { Morphem } \\
\text { es }\end{array}$} & \multicolumn{4}{|c|}{ VARIATION } \\
\hline & Cateel & Caraga & Manay & Tarragona \\
\hline $\begin{array}{c}\text { mapula } \\
\text { (red) }\end{array}$ & $\begin{array}{l}\text { mapula } \\
\text { /mapula/ }\end{array}$ & $\begin{array}{l}\text { mapuya } \\
\text { /mapuya/ }\end{array}$ & $\begin{array}{c}\text { mapul'la } \\
\text { /mapul la/ }\end{array}$ & $\begin{array}{c}\text { pul'la } \\
\text { /pul la/ }\end{array}$ \\
\hline $\begin{array}{l}\text { mala:g } \\
\text { (yellow) }\end{array}$ & $\begin{array}{l}\text { mayayag } \\
\text { /mayayag/ }\end{array}$ & $\begin{array}{c}\text { mal'lal'lag } \\
\text { /mal lal lag }\end{array}$ & $\begin{array}{l}\text { mal'lag } \\
/ \mathrm{mal} \text { lag/ }\end{array}$ & $\begin{array}{c}\text { mapul'la } \\
\text { /mapul la/ }\end{array}$ \\
\hline $\begin{array}{c}\text { grin } \\
\text { (green) }\end{array}$ & $\begin{array}{l}\text { grin } \\
\text { /grin/ }\end{array}$ & $\begin{array}{l}\text { mal'lunaw } \\
\text { /mal lunaw/ }\end{array}$ & $\begin{array}{l}\text { grin } \\
\text { /grin/ }\end{array}$ & $\begin{array}{l}\text { grin } \\
\text { /grin/ }\end{array}$ \\
\hline $\begin{array}{c}\text { bulawan } \\
\text { (gold) }\end{array}$ & $\begin{array}{l}\text { buwawan } \\
\text { /buwawan/ }\end{array}$ & $\begin{array}{l}\text { bul'lawan } \\
\text { /bul lawan/ }\end{array}$ & $\begin{array}{l}\text { bul'lawan } \\
\text { /bul lawan/ }\end{array}$ & $\begin{array}{l}\text { bulawan } \\
\text { /bulawan/ }\end{array}$ \\
\hline $\begin{array}{c}\text { iyayas } \\
\text { (wild pig) }\end{array}$ & $\begin{array}{c}\text { iyayas } \\
\text { /i:yayas/ }\end{array}$ & $\begin{array}{c}\text { il'lal'las } \\
\text { /i:1 lal las/ }\end{array}$ & $\begin{array}{c}\text { il'lal'las } \\
\text { /i:1 lal las/ }\end{array}$ & $\begin{array}{l}\text { il'lal'las } \\
\text { /i:l lal las }\end{array}$ \\
\hline $\begin{array}{l}\text { kaldero } \\
\text { (kettle) }\end{array}$ & $\begin{array}{c}\text { kadledo } \\
\text { /kadledo/ }\end{array}$ & $\begin{array}{c}\text { kol'lon } \\
\text { /kol lon/ }\end{array}$ & $\begin{array}{c}\text { kadledo } \\
\text { /kadledo/ }\end{array}$ & $\begin{array}{c}\text { sukol'l } \\
\text { /sukol 1/ }\end{array}$ \\
\hline $\begin{array}{c}\text { tasa } \\
\text { (mug) }\end{array}$ & $\begin{array}{l}\text { gal'long } \\
\text { /gal lon/ }\end{array}$ & $\begin{array}{c}\text { tasa } \\
\text { /tasah/ }\end{array}$ & $\begin{array}{c}\text { tasa } \\
\text { /tasah/ }\end{array}$ & $\begin{array}{c}\text { tasa } \\
\text { /tasah/ }\end{array}$ \\
\hline $\begin{array}{c}\text { bulak } \\
\text { (flower) }\end{array}$ & $\begin{array}{c}\text { bulak } \\
\text { /bu:l lak/ }\end{array}$ & $\begin{array}{l}\text { bunga } \\
\text { /bunah/ }\end{array}$ & $\begin{array}{c}\text { buwak } \\
\text { /bu:wak/ }\end{array}$ & $\begin{array}{c}\text { buyak } \\
\text { /bu:yak/ }\end{array}$ \\
\hline $\begin{array}{l}\text { awo } \\
\text { (fog) }\end{array}$ & $\begin{array}{c}\text { al'lo } \\
\text { /al 1o/ }\end{array}$ & $\begin{array}{c}\text { al'lo } \\
\text { /al lo/ }\end{array}$ & $\begin{array}{c}\text { al'lo } \\
\text { /al lo/ }\end{array}$ & $\begin{array}{c}\text { awo } \\
\text { /awoh/ }\end{array}$ \\
\hline $\begin{array}{c}\text { ikol'1 } \\
\text { (laugh) }\end{array}$ & $\begin{array}{c}\text { magaikol'l } \\
\text { /magai:kol 1 }\end{array}$ & $\begin{array}{c}\text { imikol'l } \\
\text { /Pi:mikol 1/ }\end{array}$ & $\begin{array}{c}\text { yumikol'l } \\
\text { /yumi:kol 1/ }\end{array}$ & $\begin{array}{c}\text { Gaikol'l } \\
\text { /gai:kol 1/ }\end{array}$ \\
\hline $\begin{array}{c}\text { galas } \\
\text { (to farm) }\end{array}$ & $\begin{array}{l}\text { gal'las } \\
\text { /gal las/ }\end{array}$ & $\begin{array}{l}\text { yagalupa } \\
\text { /yagalu.pa?/ }\end{array}$ & $\begin{array}{l}\text { magapawa } \\
\text { /magapawa? }\end{array}$ & $\begin{array}{l}\text { gapawa } \\
\text { /gapawa?/ }\end{array}$ \\
\hline
\end{tabular}

The Phoneme Schwa/Ø/

Table 4 shows the variations of the schwa / $/$ sound across the four cases. As shown in the table, the schwa/O/ sound is evident in Caraga, Manay and Tarragona Mandaya but absent in Cateel. The words listed on the table have seen with the schwa sound such as in the following words 'supsup' /sӘ:psӘp/ (to sip); 'iminum' /iminӘm/ (drink) and 'sagbot /sagbӘt/ (grass).

Among the four cases, only the Cateel do not share the same phoneme with the other municipalities. The schwa 
sound becomes extinct in Cateel due to some reasons already mentioned in the previous sections. It is prominent in Caraga because the place is still preserving the Mandaya culture, traditions, and culture. However, the young generations which are not part of this study have no longer using the schwa sound. They already substituted it with the /u/ sound as demanded by their generations.

Table 4: Variations of Use of Schwa /Ә/ in Mandaya Dialects

\begin{tabular}{|c|c|c|c|}
\hline \multicolumn{4}{|c|}{ Variations } \\
\hline Caraga & Manay & Tarragona & GLOSS \\
\hline $\begin{array}{c}\text { dubdub } \\
\text { /dӘ:bdӘb/ }\end{array}$ & $\begin{array}{c}\text { dubdub } \\
/ \mathrm{d} \partial: \mathrm{bd} \partial \mathrm{b} /\end{array}$ & $\begin{array}{c}\text { dubdub } \\
/ \mathrm{d} \partial: \mathrm{bd} \partial \mathrm{b} /\end{array}$ & stomach \\
\hline $\begin{array}{l}\text { dudungog } \\
\text { /dӘ.dӘெog/ }\end{array}$ & $\begin{array}{l}\text { dudungog } \\
\text { /dӘ.dӘnog/ }\end{array}$ & $\begin{array}{l}\text { dudungog } \\
\text { /dӘ.dӘnog/ }\end{array}$ & heard \\
\hline $\begin{array}{c}\text { sagbot } \\
\text { /sagbӘt/ }\end{array}$ & $\begin{array}{c}\text { sagbot } \\
\text { /sagbӘt/ }\end{array}$ & $\begin{array}{c}\text { sagbot } \\
\text { /sagbӘt/ }\end{array}$ & grass \\
\hline $\begin{array}{l}\text { tanum } \\
/ \tan \oslash m /\end{array}$ & $\begin{array}{c}\text { tanum } \\
/ \tan \oslash \mathrm{m} /\end{array}$ & $\begin{array}{c}\operatorname{tanum} \\
/ \tan \oslash \mathrm{m} /\end{array}$ & plant \\
\hline $\begin{array}{l}\text { supsup } \\
\text { /sӘ:psӘp/ }\end{array}$ & $\begin{array}{l}\text { supsup } \\
\text { /sӘ:psӘp/ }\end{array}$ & $\begin{array}{c}\text { supsup } \\
\text { /sӘ:psӘp/ }\end{array}$ & to sip \\
\hline $\begin{array}{l}\text { iminum } \\
\text { /iminӘm/ }\end{array}$ & $\begin{array}{l}\text { iminum } \\
\text { /iminӘm/ }\end{array}$ & $\begin{array}{c}\text { iminum } \\
\text { /iminӘm/ }\end{array}$ & to drink \\
\hline
\end{tabular}

The Vowel Lengthening

Table 5 presents another distinct characteristic of Mandaya phonology which is the lengthening of the vowel sound. As shown in the table, the four municipalities shared the same phonemes that are lengthened; these are the phonemes /a:/ and /u:/ and /i/ or /O/ for Caraga, Manay and Tarragona while Cateel has only /a:/ and /u:/.

Table 5: Variations of Vowel Lengthening in Mandaya Dialects

\begin{tabular}{|c|c|c|c|c|}
\hline \multicolumn{5}{|c|}{ Variations } \\
\hline Cateel & Caraga & Manay & Tarragona & Gloss \\
\hline $\begin{array}{l}\text { mayayag } \\
\text { /mayayag/ }\end{array}$ & $\begin{array}{c}\text { mal'lal'lag } \\
\text { /mal lal lag/ }\end{array}$ & $\begin{array}{l}\text { mal'lag } \\
\text { /mal lag/ }\end{array}$ & $\begin{array}{c}\text { yamail'lag } \\
\text { /yamai:I lag/ }\end{array}$ & Yellow \\
\hline $\begin{array}{l}\text { iyayas } \\
\text { /i:yayas/ }\end{array}$ & $\begin{array}{c}\text { il'lal'las } \\
\text { /i:1 lal las/ }\end{array}$ & $\begin{array}{c}\text { il'lal'las } \\
\text { /i:1 lal las/ }\end{array}$ & $\begin{array}{c}\text { il'lal'las } \\
\text { /i:1 lal las/ }\end{array}$ & wild pig \\
\hline $\begin{array}{c}\text { bulak } \\
\text { /bu:lak/ }\end{array}$ & $\begin{array}{l}\text { bunga } \\
\text { /bunah// }\end{array}$ & $\begin{array}{c}\text { buwak } \\
\text { /bu:wak/ }\end{array}$ & $\begin{array}{c}\text { buyak } \\
\text { /bu:yak/ }\end{array}$ & flower \\
\hline $\begin{array}{l}\text { katumbaw } \\
\text { /katu:mbaw/ }\end{array}$ & $\begin{array}{l}\text { katumbal'l } \\
\text { /katu:mbal 1/ }\end{array}$ & $\begin{array}{c}\text { katumbal'1 } \\
\text { /katu:mbal 1/ }\end{array}$ & $\begin{array}{c}\text { katumbal'l } \\
\text { /katu:mbal 1 }\end{array}$ & sili \\
\hline $\begin{array}{c}\text { magaikol } \\
\text { /magai:kol/ }\end{array}$ & $\begin{array}{c}\text { imikol'l } \\
\text { /Pi:mikol 1/ }\end{array}$ & $\begin{array}{c}\text { yumikol'l } \\
\text { /yumi:kol 1/ }\end{array}$ & $\begin{array}{c}\text { gaikol'l } \\
\text { /gai:kol 1/ }\end{array}$ & Laugh \\
\hline
\end{tabular}

The lengthened vowel is represented by this phonetic symbol /:/. In the morpheme, 'mayayag' which means color yellow is not lengthened in Cateel, 'mal'lal'lag' in Caraga and Manay but 'yamai:l'lag' in Tarragona in which the vowel / $\mathrm{i} /$ is lengthened. The vowel / $\mathrm{u} /$ is lengthened in the word 'buwak' /bu:wak/ (flower) which is evident in Cateel, Manay and Tarragona.

\section{Phoneme Substitution}

Table 6 presents the phoneme substitutions like the phoneme /1 1/ is substituted by /l/; the glide /l 1/ is substituted by $/ \mathrm{w} /$; the glide $/ 1 \sim 1 /$ is substituted by $/ \mathrm{y} /$. As shoen in the table, the word wala (/wal la:/) of Caraga is sometimes spoken by the speakers in Cateel as wala (/wala/) or vice versa depending on who the speaker was. In some other cases, the glide / / 1/ in the word gakulang (/gakul lan/ in Caraga is substituted by the phoneme / $\mathrm{w} /$ in Cateel or Taraggona, the resulting would become gakuwang (lying down). Sometimes the glide /l 1/ is substituted by the phoneme /y/ as shown in this example: Caraga's wala /wal la:/, the phoneme /1 1/ is substituted by phoneme / $\mathrm{y} /$ the resulting word is waya /waya/ which means nothing to other places. The point of reference in this section is the Mandaya in Caraga because among the cases, Caraga is identified that has the most effort in preserving the language.

Table 6: The Phoneme glide /1 1/ substitute to different Phonemes

\begin{tabular}{|c|c|c|c|c|}
\hline \multicolumn{5}{|c|}{ Variations } \\
\hline Cateel & Caraga & Manay & Tarragona & Gloss \\
\hline $\begin{array}{l}\text { mayayag } \\
\text { /mayayag/ }\end{array}$ & $\begin{array}{l}\text { mal'lal'lag } \\
\text { /mal lal lag/ }\end{array}$ & $\begin{array}{l}\text { mal'lag } \\
\text { /mal lag/ }\end{array}$ & $\begin{array}{c}\text { yamail'lag } \\
\text { /yamai:1 lag/ }\end{array}$ & yellow \\
\hline $\begin{array}{l}\text { iyayas } \\
\text { /i:yayas/ }\end{array}$ & $\begin{array}{l}\text { il'lal'las } \\
\text { /i:1 lal las/ }\end{array}$ & $\begin{array}{l}\text { il'lal'las } \\
\text { /i:1 lal las/ }\end{array}$ & $\begin{array}{l}\text { il'lal'las } \\
\text { /i:1 lal las/ }\end{array}$ & $\begin{array}{c}\text { wild } \\
\text { pig }\end{array}$ \\
\hline $\begin{array}{l}\text { bulak } \\
\text { /bu:lak/ }\end{array}$ & $\begin{array}{l}\text { bunga } \\
\text { /bunah/ }\end{array}$ & $\begin{array}{c}\text { buwak } \\
\text { /bu:wak/ }\end{array}$ & $\begin{array}{c}\text { buyak } \\
\text { /bu:yak/ }\end{array}$ & flower \\
\hline $\begin{array}{l}\text { katombaw } \\
\text { /kato:mbaw/ }\end{array}$ & $\begin{array}{l}\text { katumbal'l } \\
\text { /katu:mbal 1/ }\end{array}$ & $\begin{array}{l}\text { katumbal'l } \\
\text { /katu:mbal 1/ }\end{array}$ & $\begin{array}{c}\text { katumbal'l } \\
\text { /katu:mbal 1/ }\end{array}$ & sili \\
\hline $\begin{array}{l}\text { Magakuwang } \\
\text { /magakuwan/ }\end{array}$ & $\begin{array}{l}\text { Gakul'lang } \\
\text { /gakul lan/ }\end{array}$ & $\begin{array}{l}\text { Magaigda } \\
\text { /magai:gda?/ }\end{array}$ & $\begin{array}{l}\text { Gakul'lang } \\
\text { /gakul lan/ }\end{array}$ & $\begin{array}{l}\text { lie } \\
\text { down }\end{array}$ \\
\hline
\end{tabular}

In general, Mandaya dialects were found to be distinct from other langauges like Bisaya and Filipino because of the following: the absence of the phoneme $/ \mathrm{h} /$ in Caraga and Manay but evident in Cateel, the presence of the schwa sound in Caraga, Manay and Tarragona but absent in Cateel and the prominence of the glide /1/ or /1 1/ in Caraga, Manay and Tarragona. These three distinct characteristics of Mandaya language serve as the identity of the group.

\section{DISCUSSIONS AND CONCLUSIONS}

After conducting the phonemic inventory, it has been found out that there are 23 segmental phonemes found. Of these phonemes, 17 are consonants: /b/, /k/, /d/, /g/, /h/, /l/, $/ / \sim 1 /, / \mathrm{m} /, / \mathrm{n} /, / \mathrm{n} /, / \mathrm{p} /, / \mathrm{r} /, / \mathrm{s} /, / \mathrm{t} / / \mathrm{w} / / \mathrm{y} /$ and $/ \mathrm{P} / ; \quad 6$ vowels: /a/, $/ \mathrm{e} /, \mathrm{l} / / \mathrm{/o} /, / \mathrm{u} /$ including the schwa sound $/ \partial /$. All these phonemes can be found in Tarragona. Manay and Caraga has only 22 phonemic sounds with the absence of the phoneme $/ \mathrm{h} /$. Similarly, Cateel has found not using schwa sound. Consonant clusters are also evident, however most of them can be found in the medial position or in the beginning of the syllables such as the cluster $/ \mathrm{mp} /$ for the word /ompo?/ which means grandchild. Initial consonant clusters are also found but mostly from the loan words such as the cluster /gr/ in /grin/ which means colour green.

The data that are collected have shown the evidence of the existence of variation of Mandaya dialects in terms of phonology. This observation is supported by Labov (1966) who has posited that languages possess a whole range of 
resources for producing a giving linguistic expression. That is, variation of a language may or can exist on every level of a linguistic system, from the way we say things to the syntactic from that we choose. Benjamins (2000) has added that language variation exists because of the speakers' goal in communication, the context of the conversation, the relationship of the sender and the receiver of the message, production circumstances and any other potential factors that affects language change.

The phonological variations are attributed to the influence brought to them by migrants, intermarriages and television, social media and the influx of tourists exploring natural tourist spots in Davao Oriental. Another factor seen why there is such a variation is the Mandaya's drive to get rid of social discrimination. To go along with the trend, Mandaya's not only changing their lifestyle, clothing, attitude but as well as their language. Geographical distribution is also seen as factor that affects on the peculiarities of phonological process. Labov (1960) although outdated, has confirmed that geographical variation is apparent from the various dialects which characterize regions.

\section{RECOMMENDATIONS}

This study provides a view on the phonemic, differences of the Mandaya dialects. The findings of this study are intended for the possible contribution to the field of applied linguistics and to the possible use of teaching phonological and morphological distinctions on the language particularly on teaching speaking, reading, and writing. This may help the teacher understand more their Mandaya students in terms of difficulty in pronunciation and reading of phonomorphological features that were absent in the Mandaya language.

Further, the results of this study may be used for the preparation of instructional materials particularly on the mother-tongue curriculum of the Department of Education. This can also serve as basis for a future study on minority languages and other languages affiliated with Mandaya as origin. This current study focuses only on the segmental aspects of the Mandaya dialects with few corpora. The future research to engage related to this should focus on the supra segmental structures and intonation patterns because intonation is observed as one of the major variations of the language. In addition, a survey on the variations of the language categorizing through its geographical location such as the upland, the middle and the lowland and the age and educational qualifications of speakers may also be considered.

\section{ACKNOWLEDGMENT}

Special thanks to the Mandaya Tribe of Cateel, Caraga, Manay and Tarragona. Aissa Plasabas, Matthew, Luke and Huan, thank you for completing me.

\section{REFERENCES}

[1] Bagani, (1980). Man of Dignity. Metro-Manila: The Presidential Commission for the Rehabilitation and Development of Southern Philippines.

[2] Bauman-Waengler, J. A. (2012). Articulatory and phonological impairments. New York, NY: Pearson Higher Education.

[3] Bernthal, J., Bankson, N. W., \& Flipsen, P., Jr. (2013). Articulation and phonological disorders. New York, NY: Pearson Higher Education.

[4] Bollas, Ivy (2013). Comparative Analysis on the Phonology of Tagalog, Cebuano and Ituwis, UP Diliman, Quezon City

[5] Chambers, J. K.(2008). Studying language variation: An informal epistemology. In Chambers, J.K,Trudgill,P. andSchilling-Estes,N. (Eds). (2008). Handbook of language variation and change(715).Retrieved subscriber/book?

[6] Chambers, J.K. and Trudgill, P. (2004). Dialectology (2nded).Cambridge: Cambridge University Press.

[7] Denzin, Norman K. and Lincoln, Yvonne S. (2000, 2ed ed.). Handbook of Qualitative Research. London: Sage.

[8] Dieu M. and P. Renaud, dir. (1983), Atlas linguistique du Cameroun ALCAM: Inventaire préliminaire, Paris / Yaoundé : ACCT / CERDOTOLA.

[9] Ellis, Donald G. (1999). From Language to Communication. Routledge.

[10] Fuentes, Vilma May A. and Edito T. De la Cruz, eds. (1980). A Treasury of Mandaya and Mansaka Folk Literature. Quezon City: New Day Publishers.

[11] Geeraerts, Dirk 1987. "Types of semantic information in dictionaries". In Robert llson (ed.), A spectrum of lexicography 110. Amsterdam: John Benjamins Publishing Company.

[12] Hagen, A. (1989).Dialect, Frisian and education in the Netherlands. InCheshire et al.,(Eds). (1989).Dialect and education: Some European perspectives(48-61).Philadelphia: Multilingual Matters Ltd.

[13] Hall, Nancy (2006). Cross-linguistic patterns of vowel intrusion. Phonology 23. 387-429.

[14] Hammarström, Harald; Forkel, Robert; Haspelmath, Martin; Bank, Sebastian, eds. (2016). "Karaga Mandaya". Glottolog 2.7. Jena: Max Planck Institute for the Science of Human History.

[15] Hickey, Raymund (2014).Language Variation and Change, Campus Essen Raymond Hickey, English Linguistics https://www.uni

due.de/ELE/Language_Variation_and_Change_Introduction.pdf

[16] Holyk, Snizhana (n.d). Language Variation and Grammatical Change.

[17] Hudson, R.A. (2001). Sociolinguistics (2nded).Cambridge: Cambridge University Press.

[18] The IKSPs and CLs Research and Documentation Guidelines of 2012. NCIP Administrative Order No. 1 Series of 2012. National Commission on Indigenous People.

[19] Kiesling, Scott F. Kiesling (2011).Linguistic Variation and Change. Edinburgh University Press

[20] Language Variation and Change. http://www.linguisticsociety.org/resource/language-variation-andchange. Retrieved September 2, 2016, 3:43 PM

[21] Lincoln, YS. \& Guba, EG. (1985). Naturalistic Inquiry.Newbury Park, CA: Sage Publications.

[22] Linguistic Society of America, Language and Thought http://www.linguisticsociety.org/resource/language-and-thought retrieved December 3, 2016

[23] Llamas, C., Mullany, L and Peter Stockwell, eds. (2007). The Routledge Companion to Sociolinguistics. Routledge Publishing. Madison, New York

[24] Mandaya at Ethnologue (18th ed., 2015)

[25] Millward, C.M. \& Mary Hayes (2012).A Biography of the English Language, 3rd ed. Wadsworth.

[26] Mougeon, Raymond et al. (2010), The Sociolinguistic Competence of Immersion Students. Multilingual Matters. 
[27] Mühlhäusler, Peter. Linguistic Ecology: Language Change and Linguistic Imperialism in the Pacific Region, Routledge London and New York

[28] Ompang, Manuel B. (2015). The Mandaya Ethnic Group. NCCAhttp://ncca.gov.ph/subcommissions/subcommission-oncultural-communities-and-traditional-arts-sccta/central-culturalcommunities/the-mandaya-ethnic-group/Retrieved September 1, 2016, 10:30 PM.

[29] Poplack, S. (1993). Variation Theory and Contact. American Dialiect Research. Dennis R. Preston, ed. Philadelphia: John Benjamin B.V.

[30] Reppen, Randi et al, (2002)., Using Corpora to Explore Linguistic Variation. John Benjamins.

[31] Rickford, John R. (2002). How Linguists Approach the Study of Language and Dialect web.stanford.edu/ rickford/papers/173_reading_1.doc Retrieved on April 1, 2017.

[32] Robinson, Ava. How Language Changes Due to Social Factors https://www.theodysseyonline.com/variation-language-languagedue-social-factors-society. Retrieved on April 1, 2017.

[33] Romaine, S.(2000). Language in society: An introduction to Sociolinguistics (2nded). Oxford: OUP.
[34] Sapir, E. (1929). "The status of linguistics as a science". Language 5. 207-14. Reprinted in The selected writings of Edward Sapir in language, culture, and personality, ed. by D. G. Mandelbaum, 1606. Berkeley: University of California Press.

[35] Styler, Will. 2007. Notes from a Linguistic Mystic. http://linguisticmystic.com/2007/04/23/the- glottal-stop-your-newphonetic-phriend/ Retrieved April 5, 2017

[36] Trask, R.L. (1999/2005). Key Concepts in Language and Linguistics. Routledge.

[37] Whorf, B. L. 1940. "Science and linguistics". Technology Review 42: 227-31, 247-8.Reprinted in Language, thought, and reality: Selected writings of Benjamin Lee Whorf, ed. by J. B. Carroll, 207-19. Cambridge, MA: The Technology Press of MIT/New York: Wiley. 1956.

[38] Wondimu, Tegegne.The Use of Dialects in Education and Its Impacts on Students' Learning and Achievements. Education Journal. Vol. 4, No. 5, 2015, pp. 263269. doi: 10.11648/j.edu.20150405.22

[39] Zapata B., A. A. (2000). A handbook of general and applied linguistics. Trabajo de Ascenso sin publicar. Mérida: Escuela de Idiomas Modernos, Universidad de Los Andes. 